\title{
Forest impact on floods due to extreme rainfall and snowmelt in four Latin American environments 1: Field data analysis
}

\author{
James C. Bathurst ${ }^{\mathrm{a}, *}$, Andrés Iroumé ${ }^{\mathrm{b}}$, Felipe Cisneros ${ }^{\mathrm{c}}$, Jorge Fallas ${ }^{\mathrm{d}}$, Rodolfo Iturraspe ${ }^{\mathrm{e}}$, \\ Marcelo Gaviño Novillo ${ }^{\mathrm{f}}$, Adriana Urciuolo ${ }^{\mathrm{g}}$, Bert de Bièvre ${ }^{\mathrm{c}}$, Verónica Guerrero Borges ${ }^{\mathrm{f}}$, \\ Cristian Coello ${ }^{c}$, Pedro Cisneros ${ }^{c}$, Jorge Gayoso ${ }^{b}$, Miriam Miranda ${ }^{\mathrm{d}}$, Marco Ramírez ${ }^{\mathrm{c}}$ \\ a School of Civil Engineering and Geosciences, Newcastle University, Newcastle upon Tyne, NE1 7RU, UK \\ ${ }^{\mathrm{b}}$ Universidad Austral de Chile, Faculty of Forest Sciences, Institute of Forest Management, Independencia 641, Valdivia, Chile \\ ${ }^{\mathrm{c}}$ Universidad de Cuenca, Programa para el Manejo de Agua y Suelo (PROMAS), Department of Water and Soil Resources Engineering, Avenida 12 de abril S/N, Cuenca, Ecuador

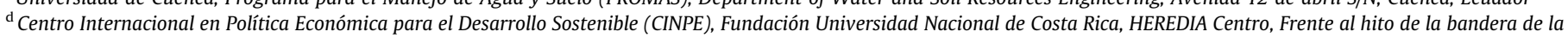 \\ Universidad Nacional, 555-3000 San José, Costa Rica \\ e Centro Austral de Investigaciones Científicas, Ushuaia, Argentina \\ ${ }^{\mathrm{f}}$ Facultad de Ingeniería, Departamento de Hidráulica, Universidad Nacional de La Plata, Calle 47 N1/4 20, 1900 La Plata, Argentina \\ ${ }^{\mathrm{g}}$ Secretaría de Desarrollo Sustentable y Ambiente de Tierra del Fuego, San Martín 1401, 9410 Ushuaia, Argentina
}

\section{A R T I C L E I N F O}

\section{Article history:}

Received 16 March 2010

Received in revised form 1 September 2010

Accepted 26 November 2010

Available online $\mathrm{xxxx}$

This manuscript was handled by

Konstantine P. Georgakakos, Editor-in-Chief, with the assistance of Günter Blöschl,

Associate Editor

\section{Keywords:}

Field data

Forest

Floods

Forest cover change

Latin America

River catchments

\begin{abstract}
S U M M A R Y
Flood peak data for focus catchments in Costa Rica, Ecuador, Chile and Argentina are analyzed to test the hypothesis that, as the size of the hydrological event increases, the effect of forest cover on the peak discharge becomes less important. Previous research suggests that this hypothesis may hold for small catchments (less than $1 \mathrm{~km}^{2}$ ) but the pattern is less clear for large catchments. The principal study results are for small paired catchments $\left(0.6-10 \mathrm{~km}^{2}\right)$ with different forest covers (forest/pasture) in highland Ecuador and a small $\left(0.35 \mathrm{~km}^{2}\right)$ plantation catchment in southern Chile subjected to logging. The former were analyzed by comparing the corresponding peak discharges for given rainfall events, the latter by comparing the relationships between peak discharge and rainfall event size for the pre- and post-logging periods. In all cases there is relative or absolute convergence of the responses as discharge increases, with convergence likely for flood return periods of around 10 years. More limited data for larger catchments which have undergone either deforestation or afforestation $\left(131 \mathrm{~km}^{2}\right.$ in Costa Rica and $94-1545 \mathrm{~km}^{2}$ in Chile) suggest that the percentage change in forest cover must exceed $20-30 \%$ to provoke a measurable response in peak discharge; convergence of peak discharge response at high flows (return periods of around 5 years) for the different forest covers may then be observed. For a $12.9-\mathrm{km}^{2}$ snowmelt-affected catchment in Tierra del Fuego, Argentina, extreme floods require rain-on-snow events but the data are not sufficient to quantify the complex relationship between forest cover, event return period and peak discharge. In general, forest cover is unlikely to reduce, significantly, peak discharges generated by extreme rainfall but may still offer substantial mitigation benefits for moderate (i.e. more frequent) rainfall events.
\end{abstract}

(c) 2011 Elsevier B.V. All rights reserved.

\section{Introduction}

Forests are perceived by the public as "good things" which reduce floods and minimize soil erosion. Deforestation and logging are therefore regularly blamed for exacerbating the disastrous effects of floods generated by extreme rainfall, such as hurricanes. Government and development agency water resources policies tend to adhere to this perception; consequently large sums of money are invested in reforesting headwater areas of river catch-

\footnotetext{
* Corresponding author. Tel.: +44 1912225431.

E-mail address: j.c.bathurst@ncl.ac.uk (J.C. Bathurst).
}

ments and forest cover controls are imposed on the (typically poor) populations living in these areas (CIFOR and FAO, 2005; Calder, 2005; Calder and Aylward, 2006). However, the impact of forest management on river catchment response for extreme rainfall and snowmelt events is an area in which there is considerable scientific uncertainty as well as poorly conceived policy. In particular, while forests may reduce floods for small to moderate storms, there is growing evidence that this effect is increasingly reduced as rainfall increases to more extreme levels (e.g. Beschta et al., 2000; Sikka et al., 2003; López-Moreno et al., 2006). The EPIC FORCE project (Evidence-based Policy for Integrated Control of Forested River Catchments in Extreme Rainfall and Snowmelt) (http://research.ncl.ac.uk/epicforce), funded by the European 
Commission, was therefore set up to develop policy recommendations for the integrated management of forest and water resources in the Latin American environment, based on improvements in understanding of the effects of forest cover on catchment response for extreme rainfall and snowmelt events and the creation of a framework within which to develop management strategies (Bathurst et al., 2010). This paper and its companion paper (Bathurst et al., 2011) discuss the relationship between forest cover and catchment response. Discussion of the management and policy aspects is presented elsewhere (Bathurst et al., 2010; Mao et al., 2008; Mintegui and Robredo, 2008).

For focus sites in Costa Rica, Ecuador, Chile and Argentina, a combination of field data analysis and model application was used to test the hypothesis that, as the size of the hydrological event increases, the effect of forest cover on the peak discharge becomes less important. The aim of the field data analysis was to use field measurements to quantify directly the impact of forest cover on catchment response to extreme rainfall or snowmelt. This work is reported here. The model applications were intended to extrapolate the data analyses over a wider range of conditions and to provide a systematic analysis of the impact of forest cover on flood peak discharge using a standard approach. These applications are presented in the companion paper (Bathurst et al., 2011).

The hypothesis being examined is illustrated in Fig. 1, which shows the relationship between peak discharge and flood frequency (represented by return period) for catchments which are identical except for the level of forest cover. In both cases, the less frequent the flood (i.e. the larger the return period), the greater is the peak discharge. For moderate floods, which are relatively frequent, the forested catchment is assumed to be able to absorb more rainfall into the soil and therefore has lower peak discharges than the non-forested catchment. This is because the greater interception of rainfall by the forest, combined with a higher transpiration by the trees, allows the build up of greater soil moisture deficits compared with the non-forested case. However, the effect of the deficit is expected to decrease as rainfall amounts increase. The diagram thus proposes a convergence of peak discharge response for the more extreme floods.

The paper establishes the current state of the knowledge, describes the focus sites and the data availability, presents the analysis strategy and results and discusses the effects of forest cover on flood peak discharge and the extent to which the hypothesis is supported. There is a relative lack of direct evidence concerning the effect of forest cover on flood peak discharge in extreme rainfall and snowmelt events. In particular, there have been only a few field studies and these have mostly concentrated on the Pacific Northwest of North America. The paper therefore both adds to the data-

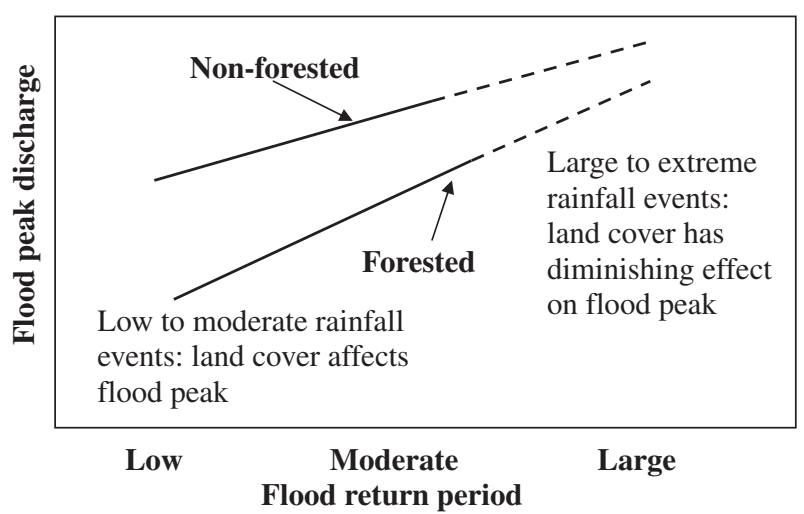

Fig. 1. The hypothesis that, as the size of the flood peak increases, the effects of forest cover become less important. base and extends the previous research to the Latin American environment; further, by considering a range of focus sites, it consolidates the results at a more general scale.

For the purposes of the paper, "extreme rainfall" refers to high rainfall, generating floods, and does not include low rainfall responsible for droughts. No quantitative definition, e.g. in $\mathrm{mm}$, is offered as this will vary between catchments. However, on the basis of the above hypothesis, a partial definition might refer to the amount above which the effect of forest cover on the flood peak discharge becomes unimportant. A definition of extreme event in terms of damage caused by the event is discussed in Bathurst et al. (2010).

\section{Field studies of forest impacts on floods}

The biophysical controls on floods are complex, typically involve conflicting processes and can be explained only through multidisciplinary considerations (e.g. Hamilton, 1987; Forsyth, 1998; Calder, 2005). Decades of research have shown that forest cover reduces annual runoff because of increased rainfall interception and increased transpiration during dry periods (e.g. Bosch and Hewlett, 1982; Calder, 1990; Cornish, 1993; Rowe and Pearce, 1994; Stednick, 1996; Fahey and Jackson, 1997; Andréassian, 2004; Bruijnzeel, 2004). Theoretical considerations suggest that interception by forests should also reduce floods by removing a proportion of the storm rainfall and by allowing higher soil moisture deficits, relative to areas without forests. However, these effects are expected to be most significant for small storms and to be increasingly less effective as rainfall amounts increase.

Research into quantifying the impact of forests on response to extreme rainfalls, or on the variation of the response for events of different frequencies, is very limited. In an unprecedented global scale study, Bradshaw et al. (2007) analyzed data for Africa, Asia and Central and South America. Working at the country scale, they found that flood frequency is negatively correlated with the amount of remaining natural forest and positively correlated with natural forest area loss. They thus linked removal of forest with increased flooding. However, they specifically excluded flood events originating independently of the landscape characteristics, such as hurricanes, so it is not clear to what extent their conclusions apply to extreme rainfall events. Further, the use of the country scale does not easily allow the controlling processes to be identified. Bradshaw et al.'s interpretation of their statistics has also been challenged (van Dijk et al., 2009), highlighting the difficulty of deriving clear, unambiguous evidence of the role of forests in large floods.

Research at the smaller scale of the river catchment has been largely concentrated in the Pacific Northwest of North America. At catchment scales of around $1 \mathrm{~km}^{2}$, peak discharges generally increase following logging but in most (although not all) cases, the percentage increase decreases as the discharge increases (Jones and Grant, 1996; Thomas and Megahan, 1998; Beschta et al., 2000; Moore and Wondzell, 2005). Beschta et al. (2000) in particular found that, for flood return periods of 5 years or more, the effect of forest treatments on the peak discharge either disappeared or else was too small to be discernible (i.e. within the measurement error margin). However, the available data set contained hardly any events with larger return periods. Sikka et al. (2003), analyzing data for 32-ha paired catchments with contrasting covers of eucalyptus and grassland with native forest in southern India, suggest that there is a convergence of response at the higher flows (with return periods of perhaps 10 years according to their probability plots of peak discharge). Similarly Lane et al. (2005), analyzing flow duration curves for 10 southern hemisphere catchments (mostly in the range 30-300 ha), found that the greatest 
proportional effect of afforestation was on the median and lower, rather than higher, flows. At the larger catchment scale the picture is less clear. Lyons and Beschta (1983), for a catchment of $668 \mathrm{~km}^{2}$, found a trend of increasing peak flow magnitude during a period of relatively rapid increase in logging and forest road building but did not have sufficient ancillary data to determine the cause of the increase unambiguously. For three catchments of $60-600 \mathrm{~km}^{2}$, Jones and Grant (1996) found an increase in peak discharges following forest treatment activities but Thomas and Megahan (1998) and Beschta et al. (2000), analyzing the same data, did not, a difference that highlights the complexities of identifying appropriate analytical approaches and generalizing from limited datasets. Pizarro et al. (2006), analyzing data for the $259-\mathrm{km}^{2}$ Purapel catchment in central Chile, were unable to attribute variations in peak flows to a $44 \%$ loss of native forest because of a compensating $52 \%$ increase in radiata pine plantation. They found instead a greater dependency on precipitation. Wilk et al. (2001) similarly found no increase in water yield in a $12,100-\mathrm{km}^{2}$ catchment in Thailand, despite extensive deforestation, again possibly because of compensating increases in other vegetation covers. By contrast, Costa et al. (2003) found, for a $175,360-\mathrm{km}^{2}$ catchment in South America, that replacement of natural vegetation by agricultural covers could produce a significant increase in annual mean discharge and high-flow season discharges, as a result of reduced infiltration and evapotranspiration rates. In Europe, Robinson et al. (2003) note that at the local scale there are specific conditions where forest impacts on peak flows are potentially significant (as a function of management activity, soil type and tree type) but, at the broad European or regional scale, forestry activity has relatively little impact on extreme flows (either high or low). On the other hand, López-Moreno et al. (2006), analyzing data for 18 gauging stations (catchment areas of $50-2800 \mathrm{~km}^{2}$ ) in the central Spanish Pyrenees, found that increased vegetation cover following farmland abandonment and reforestation caused decreases in the 5- and 25-year return period floods over a period of 50 years. However, there was no discernible difference in the respective reductions (similar ranges of around $8-46 \%$ and the same mean reduction of $26 \%$ ), which suggests that forest cover change does continue to affect peak discharges as discharge increases, at least for flood return periods up to 25 years.

In summary, available research tends mostly to support the hypothesis that, as the size of the hydrological event increases, the effect of forest cover becomes less important, at least for small catchments; convergence of response for different forest covers is apparent for flood return periods of 5-10 years. Thus, forest cover may not significantly reduce peak flows during extreme events but could be effective during more frequent, less intensive rainstorms, noticeably reducing the frequency and intensity of floods (LópezMoreno et al., 2006). From an economic point of view, though, planting forests to reduce flooding may show little benefit for the larger floods while having the unwelcome effect of reducing water availability at the annual scale or at times of low flow (e.g. Sikka et al., 2003). For large catchments the pattern may be masked by diluting and attenuating effects but it may still be apparent for large scale land-use changes. Overall, then, the evidence in favour of the hypothesis is still too weak to be conclusive and there are some contrary findings. In particular there is a lack of data for providing both clear support and identification of the flood return period at which convergence occurs. A number of broader issues also remain to be resolved. The available research needs to be extended with a wider availability of extreme rainfall data and for other forest environments (DeWalle, 2003). It is important also to distinguish between the effect of removal of cover (i.e. forest biomass) and the effect of the practices used in that removal, including logging technique and road building (e.g. La Marche and Lettenmaier, 2001; DeWalle, 2003). The provision of forest roads, for example, may effectively increase stream network density and contribute to an increase in flood levels. The contribution from snowmelt also needs to be isolated. Generally, snowmelt rates appear to be higher in logged areas than under forest cover (e.g. Marks et al., 1998; Monteith et al., 2006; Jost et al., 2007). Current thinking suggests that rain-on-snow events can be significantly increased by logging, because of greater accumulations of snow in cleared areas prior to rain-on-snow events and because of enhanced latent and sensible heat transfer in logged areas, resulting from increased surface wind (Storck et al., 1998). For very large storms, though, much of the snow may melt during the storm, whether or not the rate is enhanced, and the effect of forest cover change may then be reduced.

Less controversially forests are perceived to limit catchment sediment yield by protecting the soil against erosion. Thus forest logging generally results in an increase in soil erosion and sediment delivery to the river network (e.g. Amaranthus et al., 1985; Davies and Nelson, 1993; Guthrie, 2002), although again much of this may be attributed to logging technique and forest roads (e.g. Reid and Dunne, 1984; Grayson et al., 1993; Croke et al., 1999). Forests protect the soil from erosion by raindrop impact but may cause erosion as a result of leaf drip impact. The type of tree is important: tree species with large leaves generate the largest water drop sizes and thus maximize drip impact erosion (Hall and Calder, 1993; Calder, 2005). This is especially so if there is no understorey or litter. There is a need, therefore, to understand the impacts of different tree species on leaf drip erosion in extreme rainfalls, contrasting for example commercial plantations of exotic species with native forests. Forests also protect against shallow landslide erosion through their root-binding action and by generating higher soil moisture deficits (i.e. drier soils) which allow reduced soil pore water pressures (e.g. Amaranthus et al., 1985; Bruijnzeel, 2004). This protection has been found to remain effective at extreme rainfalls (Phillips et al., 1990), at least for mature forests. However, when landslides do occur on forested slopes, in extreme rainfall and wind events such as the 1998 Hurricane Mitch in Central America, it is possible that they may be larger and more destructive than on unforested slopes. They could then evolve into debris flows which deliver large volumes of sediment and woody debris to the channel network (e.g. Eschner and Patric, 1982; DeGraff et al., 1989, Fig. 20).

Considering the complex interaction between forest management and flood response, DeWalle (2003) recommended that the primary focus for our next improvement in understanding should be a programme of research into the impacts of forest management on response to extreme rainfall, with clear distinction made between types of forest and logging procedure. The outcome of such a programme could help to guide the practice of forest management in the future and to reshape the attitudes of the general public. Although not able to consider management practices, the EPIC FORCE project followed this recommendation by investigating the impact of forest cover on peak discharges for extreme rainfall and snowmelt events for a range of forest types in Latin America.

\section{Focus areas}

The focus areas represent both tropical and temperate rain forests and are subjected to extremes of rainfall from hurricanes, El Niño events and mid-latitude depressions and, in the case of Argentina, to snowmelt. Data were collected in instrumented river catchments as follows; the Pejibaye catchment $\left(131 \mathrm{~km}^{2}\right)$ in southern Costa Rica, a set of sub-catchments $\left(2.3-10 \mathrm{~km}^{2}\right)$ in the Rio Chanchán catchment $\left(1409 \mathrm{~km}^{2}\right)$ in Ecuador, a set of experimental forest catchments $\left(0.03-6 \mathrm{~km}^{2}\right)$ in southern Chile and a pair of experimental catchments (12.9 and $18 \mathrm{~km}^{2}$ ) in Tierra del Fuego, Argentina (Fig. 2). Table 1 summarizes their general environments. For practical reasons the catchments are generally small. However, 
in Costa Rica and Chile it was possible to extend the analysis to larger catchments, hundreds to thousands of square kilometres in area. It is important to consider the larger scale because: (1) responses observed at small scales may be attenuated or diluted at larger scales, especially where forest logging or plantation is phased across the catchment or where only part of the catchment is forested; and (2) larger scales are more relevant to planning considerations and provide a more appropriate basis for making policy recommendations to national agencies.

Flow duration curves for the principal catchments are shown in Fig. 3, noting that their reliability is limited by the short periods of available record.

\subsection{Costa Rica focus area}

The Pejibaye catchment on the Pacific slopes of Costa Rica was selected to represent an area subject to hurricane rainfall: indeed

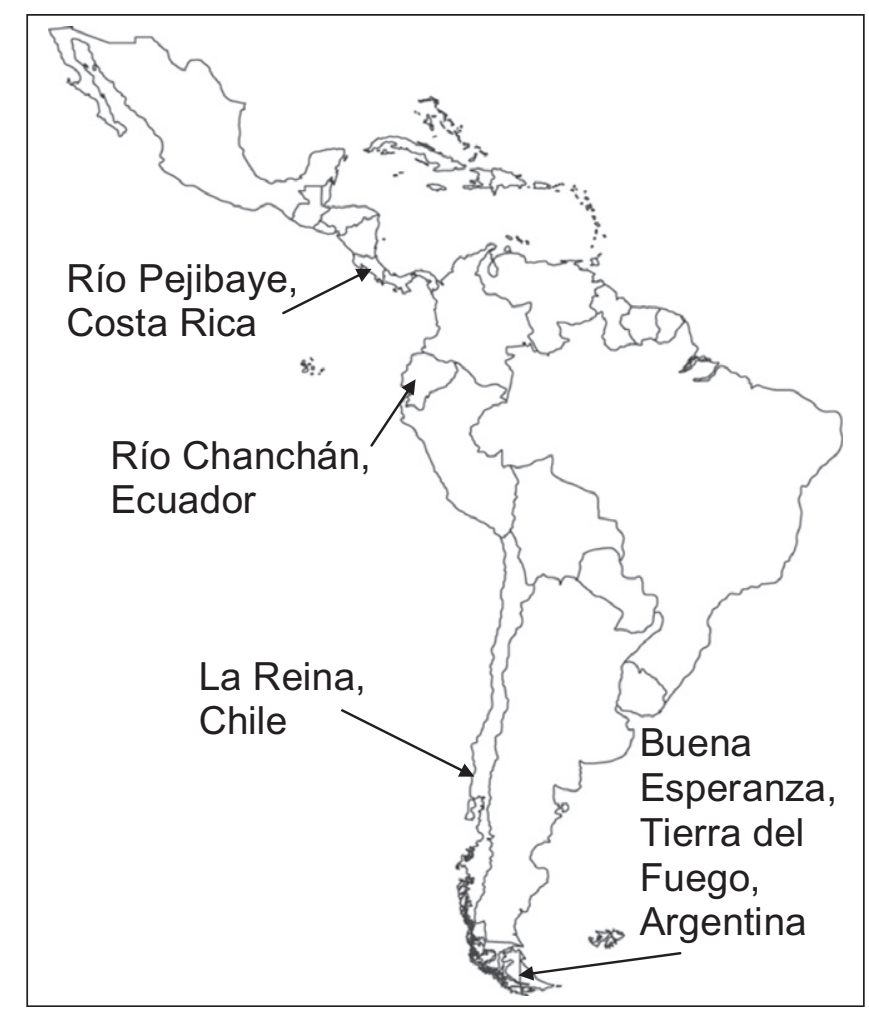

Fig. 2. Location map for the focus sites. Reproduced from Bathurst et al. (2010) by permission of Taylor \& Francis Ltd (http://www.informaworld.com). the river gauging station was destroyed by hurricane César in 1996! The area was also affected by Hurricane Mitch in 1998. The Pejibaye is a tributary of the Río General, which in turn joins the Río Grande de Térraba, which discharges into the ocean. The catchment is defined by the gauging station, which belonged to the Instituto Costarricense de Electricidad, with elevations ranging from $345 \mathrm{~m}$ at the gauging station up to $1100 \mathrm{~m}$. The soils are sandy-clay and silty-clay, are moderately deep to deep (less than $1 \mathrm{~m}$ deep) and have a low to moderate permeability (Acón $\mathrm{y}$ Asociados, 1991). Since 1950 the original forest cover has been largely replaced by cattle pasture, coffee plantation and some arable cultivation; the percent natural forest cover was $98.1 \%$ in 1948 , $31.7 \%$ in 1961 and $3.8 \%$ in 2005 . Daily precipitation has been measured from around 1970 at three sites in and around the catchment: Bolivia situated near the middle of the catchment, Aguas Buenas in the north-west corner of the catchment and Cristo Rey around $4 \mathrm{~km}$ north of the catchment. Hourly precipitation data are available for Bolivia for 1991-1993. Mean annual precipitation is $2262 \mathrm{~mm}$ (for the period 1969-2005) with slightly higher values in the upper part of the catchment and lower values towards the outlet. Most of the precipitation falls during the wet season from May to November. As an example of the extreme values, tropical depression Gert delivered a 24-h rainfall of $332 \mathrm{~mm}$ at the Bolivia gauge in September 1993. Mean daily discharge data at the outlet are available from 1969 to 1996 together with the highest maximum discharge for each month. Daily potential evaporation has been measured with an evaporation pan at Bolivia since 1972 (mean annual value of $1294 \mathrm{~mm}$ ) while the mean evapotranspiration by mass balance (i.e. rainfall minus discharge) is $786 \mathrm{~mm}$. Annual runoff varies in close correspondence to the rainfall. For 1975-1995, the mean annual runoff was $1324 \mathrm{~mm}$ (CV 33\%), the minimum being $711 \mathrm{~mm}$ in 1991 and the maximum being $2174 \mathrm{~mm}$ in 1981. Individual years are affected by the variations of the El Niño Southern Oscillation. For 1975-1995, average runoff was $967 \mathrm{~mm}$ for El Niño years, $1611 \mathrm{~mm}$ for La Niña years and $1405 \mathrm{~mm}$ for neutral years. The corresponding evapotranspirations determined by mass balance are 785, 909 and $718 \mathrm{~mm}$. Further details are given in Fallas and Valverde (2007).

\subsection{Ecuador focus area}

The Río Chanchán catchment in the central Andean region of Ecuador is part of the Guayas system, which drains to the Pacific Ocean. Catchment elevation ranges from $340 \mathrm{~m}$ to $4480 \mathrm{~m}$. Mean annual rainfall varies considerably with altitude and location, from under $700 \mathrm{~mm}$ at the lower elevations to over $1300 \mathrm{~mm}$ at higher elevations, mostly falling between January and May. Total amounts may be rather higher in El Niño years and the wet season may then last from November to June. Recent major El Niño years are

Table 1

Overview of the four focus areas.

\begin{tabular}{|c|c|c|c|}
\hline Focus area and location & $\begin{array}{l}\text { Climatic } \\
\text { classification }^{*}\end{array}$ & Precipitation characteristics & Forest cover \\
\hline $\begin{array}{l}\text { Pejibaye catchment }\left(131 \mathrm{~km}^{2}\right) \text {, } \\
\text { southern Costa Rica }\end{array}$ & $\begin{array}{l}\text { Am: Tropical - } \\
\text { monsoon }\end{array}$ & $\begin{array}{l}\text { Seasonal rainfall including hurricanes }(1988,1993,1996 \text {, } \\
\text { 1998) }\end{array}$ & $\begin{array}{l}\text { Rapid forest conversion to pasture/coffee } \\
\text { plantation; water resource degradation }\end{array}$ \\
\hline $\begin{array}{l}\text { Sub-catchments at scale } \\
1-10 \mathrm{~km}^{2} \text { in Rio Chanchán } \\
\text { catchment }\left(1409 \mathrm{~km}^{2}\right) \text {, } \\
\text { Ecuador }\end{array}$ & $\begin{array}{l}\text { Aw/Am: Tropical } \\
\text { - savannah/ } \\
\text { monsoon }\end{array}$ & $\begin{array}{l}\text { Seasonal rainfall with severe El Niño effects (e.g. 1982/ } \\
\text { 1983, 1997/1998) or severe rainfall (e.g. 2007/2008) }\end{array}$ & $\begin{array}{l}\text { Rapid forest conversion to agriculture/secondary } \\
\text { vegetation/exotic plantation }\end{array}$ \\
\hline $\begin{array}{l}\text { Experimental forest catchments } \\
\text { (especially La Reina, } \\
0.35 \mathrm{~km}^{2} \text { ) in southern Chile }\end{array}$ & $\begin{array}{l}\text { Cfb: Temperate } \\
\text { - no dry season, } \\
\text { warm summer }\end{array}$ & $\begin{array}{l}\text { High seasonal and all year rainfall (up to } 4000 \mathrm{~mm} \text { ) with } \\
\text { large interannual variability from El Niño effects }\end{array}$ & $\begin{array}{l}\text { Extensive exotic, short rotation plantations; } \\
\text { native forest logging and degradation }\end{array}$ \\
\hline $\begin{array}{r}\text { Buena Esperanza }\left(12.9 \mathrm{~km}^{2}\right) \text { and } \\
\text { Hambre }\left(18 \mathrm{~km}^{2}\right) \text { catchments } \\
\text { in Tierra del Fuego, Argentina }\end{array}$ & $\begin{array}{l}\text { ET: Polar - } \\
\text { tundra }\end{array}$ & $\begin{array}{l}\text { Moderate and frequent precipitation all year from frontal } \\
\text { systems, enhanced by orographic effect; extreme events } \\
\text { from combined rainfall and snowmelt (e.g. 1954). }\end{array}$ & $\begin{array}{l}\text { Native forest exploitation; forest regeneration } \\
\text { impeded by cattle introduction; tourist activities } \\
\text { affect the natural environment and water quality. }\end{array}$ \\
\hline
\end{tabular}

Based on the updated Köppen-Geiger classification of Peel et al. (2007). 
(a) Pejibaye, Costa Rica

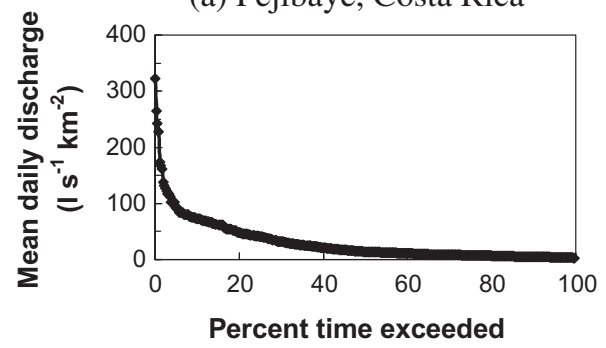

(c) La Reina, Chile

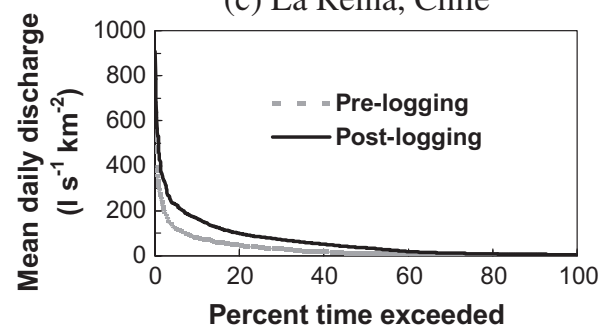

(b) Ecuador microcatchments

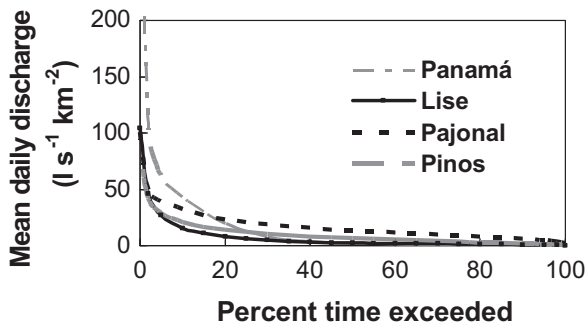

(d) Buena Esperanza, Tierra del Fuego, Argentina

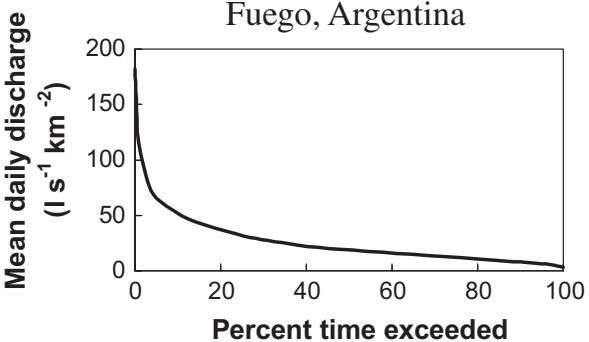

Fig. 3. Flow duration curves for the principal focus catchments.

1982-1983 and 1997-1998. A range of soils has developed, varying with altitude. In particular, the upper elevations are characterized by andosols, classified according to the United Nations Food and Agriculture Organization's (FAO) World Reference Base for Soil Resources (FAO/ISRIC/ISSS, 1998). These have a high organic content and remarkable water-holding properties, enabling them to release water at an almost constant rate through the dry season (e.g. Buytaert et al., 2005; Harden, 2006). Forest cover and vegetation change from the higher to lower elevations in the sequence páramo (characteristic grassland on the andosols), pasture, cultivated land and pasture, and mattoral. A number of experimental micro-catchments were set up in the project to study the hydrological responses of different land covers and two sets of neighbouring pairs with contrasting covers provide the focus of the flood studies. These are the Lise/Panamá and Pinos/Pajonal pairs, the main characteristics of which are given in Table 2. The latter pair is also described in Buytaert et al. (2007). All the catchments are on steeply sloping land with a considerable elevation range. In each case, rainfall data were collected in at least two tipping bucket gauges (logged at a minimum interval of $5 \mathrm{~min}$ ) and outlet discharge was measured (at 15-min intervals) with a V-notch weir and pressure transducer. However, some of the discharge record is likely to have been affected by difficulties in establishing the high discharge end of the stage-discharge rating curves. The available data records for the micro-catchments are limited to 2 or 3 years from 2005 but longer term context is provided by two gauging stations along the
Río Chanchán and by around five raingauges throughout the catchment.

\subsection{Chile focus area}

The Chile focus area (Lakes Region, $41^{\circ} \mathrm{S}$ ) typifies the large scale forest plantation of southern central Chile, based on exotic, short rotation species such as radiata pine or eucalyptus. The area is characterized by high winter and all year rainfall, with large interannual variability from El Niño effects. The main test catchment was the $0.35-\mathrm{km}^{2}$ La Reina catchment, approximately $60 \mathrm{~km}$ south of Valdivia in the Coastal Range. This was planted over $79.4 \%$ of its area with radiata pine in 1977, the remaining area being covered with deciduous riparian vegetation and forest roads. During October 1999 to February 2000 the radiata pine was clearfelled and the area was then replanted with Eucalyptus nitens in June-July 2000.

La Reina was instrumented in 1996-1997 and full data are available from April 1997, apart from a gap from November 2003 to July 2005. These include hourly discharge data from the flume at the catchment outlet and hourly meteorological data from an automatic weather station at the edge of the catchment. The data are generally of a good quality although some infilling of the meteorological data was necessary (from June to September 2002 because of problems with the precipitation measurements). There were also some uncertainties with the discharge data from 2002. A few samples have been taken of suspended sediment

Table 2

Characteristics of the principal focus catchments in Ecuador.

\begin{tabular}{|c|c|c|c|c|}
\hline \multirow[t]{2}{*}{ Catchment characteristic } & \multicolumn{4}{|l|}{ Experimental catchment } \\
\hline & Lise & Panamá & Pinos & Pajonal \\
\hline Area $\left(\mathrm{km}^{2}\right)$ & 2.34 & 10.01 & 0.59 & 1.003 \\
\hline Forest cover/vegetation & $\begin{array}{l}18.5 \% \text { shrubland } 81.5 \% \\
\text { forest }\end{array}$ & $\begin{array}{l}16.5 \% \text { cropland } 57 \% \text { pasture } 26.5 \% \\
\text { forest }\end{array}$ & $98 \%$ pine forest & $\begin{array}{l}14 \% \text { shrubland } 86 \% \text { grassland (cattle } \\
\text { pasture) }\end{array}$ \\
\hline Elevation range $(\mathrm{m})$ & $1695-3240$ & $2050-3080$ & $3240-3700$ & $2980-3740$ \\
\hline Soil type (FAO/ISRIC/ISSS, 1998) & Mostly leptosols & Mostly cambisols and leptosols & $\begin{array}{l}\text { Mostly } \\
\text { andosols }\end{array}$ & Mostly andosols \\
\hline Mean annual rainfall (mm) & 793 & 962 & 940 & 1030 \\
\hline $\begin{array}{l}\text { Mean annual discharge } \\
\quad\left(1 \mathrm{~s}^{-1} \mathrm{~km}^{-2}\right)\end{array}$ & 8.40 & 12.65 & 6.31 & 15.5 \\
\hline Mean annual runoff (mm) & 265 & 399 & 199 & 489 \\
\hline Runoff/rainfall ratio & 0.306 & 0.414 & 0.211 & 0.474 \\
\hline
\end{tabular}


concentration at the outlet. Annual precipitation is around $2500 \mathrm{~mm}$ year $^{-1}$, mostly from frontal rainfall in the winter (JuneAugust). Annual potential evaporation is around $1000 \mathrm{~mm}_{\text {year }}{ }^{-1}$. Soils are mainly well drained with measured depths of $0.5-1.9 \mathrm{~m}$. Soil samples collected from three soil pits (two samples in each pit) by the Corporación Nacional Forestal give sand-silt-clay percentages of $47.6 \%, 33.8 \%$ and $18.6 \%$ respectively. Soil hydraulic properties were measured by Duhalde Schwarzenberg (1999) and Sáez García (1999), the mean conductivity being $4.18 \mathrm{~m} \mathrm{day}^{-1}$ from five infiltration tests.

Data were also available for a number of other catchments with varying conditions of forest cover (Iroumé et al., 2006a). Longer term context is provided by the 45 -year record of daily precipitation data for the Isla Teja weather station at Valdivia. The analysis was extended to three larger catchments further north in the Bíobío Region $\left(37^{\circ} \mathrm{S}\right.$ ) (Caramávida, $94 \mathrm{~km}^{2}$; Mulchén, $434 \mathrm{~km}^{2}$; and Duqueco, $1545 \mathrm{~km}^{2}$ ) which have undergone significant plantation on former agricultural lands affecting at least 30\% of the catchment area.

\subsection{Argentina focus area}

The Argentina focus area was selected to incorporate snowmelt and rain-on-snow events. The main test site was the $12.9-\mathrm{km}^{2} \mathrm{Ar}-$ royo Buena Esperanza catchment in Tierra del Fuego, which has a native forest cover over about $36 \%$ of its area, at the lower to middle elevations, and a small glacier at its head. It debouches onto the city of Ushuaia in the Tierra del Fuego province of Argentina and provides the city's water supply. Elevations range from $140 \mathrm{~m}$ at the outlet up to $1250 \mathrm{~m}$, there is forest cover up to $550 \mathrm{~m}$ and bare ground at higher elevations, where there is a small ski station. Mean annual precipitation ranges from $530 \mathrm{~mm}$ in Ushuaia to $1300 \mathrm{~mm}$ in the upper part of the catchment and is spread evenly throughout the year, failing mainly as snow in the winter (MaySeptember). There is currently no forest logging, although there has been some in the past. A second catchment, the Arroyo Hambre $\left(18 \mathrm{~km}^{2}\right)$, was instrumented to provide data for the contrasting state of a site distant from, and generally unaffected by, human activity. However, the major emphasis during the project was on the Buena Esperanza.

Intensive monitoring of the Buena Esperanza catchment has been carried out for a number of years and an excellent set of data, for the period $1 / 5 / 2005$ to $30 / 4 / 2007$, was available for analysis. This includes hourly discharge at the Buena Esperanza outlet and the Martial $\left(4.8 \mathrm{~km}^{2}\right)$ and Godoy $\left(1.5 \mathrm{~km}^{2}\right)$ sub-catchments. Hourly precipitation has been measured at the Aerosilla site (at $500 \mathrm{~m}$ elevation within the Buena Esperanza catchment) for the entire period. However, this raingauge is not suitable for snow collection and therefore underestimates precipitation data in the winter. To overcome this problem, data from two rain-snow collectors, at 220 and 550 m elevation were used to determine the precipitation variation with altitude, based on a correlation with data for Ushuaia. These data were collected at 10-day intervals. There are also daily precipitation data (and some hourly data) at Ushuaia (at sea level) for the entire period, which include rain and snow. Hourly temperature data are available for the entire period at Ushuaia and the Martial glacier (1000 m elevation). In addition there is estimated daily potential evaporation at elevations of $120 \mathrm{~m}$ and $600 \mathrm{~m}$.

The lower part of the catchment is mainly pine forest, apart from the flatter areas where it is marshy. Above this there is deciduous forest and then grassland in the upper main valley bottom. Because of the extreme conditions the remainder of the catchment is made up of rock debris of different thicknesses. The soil type generally varies with the vegetation type. Under the forests there is an organic soil on top of a glacial till and in the marshy areas there is a deep peat soil. The grassland area also has an organic soil on top of a glacial till and higher than that there is little or no soil.

The extreme event of 5/11/1954 caused major flooding in Ushuaia with a peak discharge of around $13 \mathrm{~m}^{3} \mathrm{~s}^{-1}$. This was a result of both heavy rain $(42 \mathrm{~mm}$ in $9 \mathrm{~h}$ at Ushuaia with a corresponding estimated value of $94.5 \mathrm{~mm}$ above $600 \mathrm{~m}$ ) and snowmelt, especially in the lower part of the catchment. The source of the snowmelt was an unusually large accumulation of snow during August-September which had been well preserved through October, as that month was colder than normal. During the event, temperatures of up to $15^{\circ} \mathrm{C}$ at Ushuaia meant that the precipitation fell as rain over the entire catchment. The return period of the event daily rainfall for Ushuaia is 17.4 years if the entire rainfall record is considered. If the rainfall record only for days with a temperature of greater than $6{ }^{\circ} \mathrm{C}$ at Ushuaia is considered (meaning that precipitation is in liquid form for most of the catchment), the return period is 70.8 years. The discharge record is too short for an accurate quantification of the return period for the peak flow but the period is considered to be more than 100 years.

\section{Data analysis}

Because of the different availabilities of instrumented catchment, different approaches to the data analysis were followed in the focus areas.

\subsection{Costa Rica focus area}

The original aim was to compare the Pejibaye catchment response from when there was significant forest cover with the present-day response. However, the data record limited the analysis to the period from 1970. From 1970 to 2000 the percentage of the catchment covered by native forest fell steadily from about $20 \%$ to $3.5 \%$ but this was to some extent compensated for by an increase in the area under coffee cultivation from $9 \%$ to $20 \%$ during $1973-$ 2000. There is no significant difference between the mean annual discharges for the decades 1970s, 1980s and 1990s (Kruskal-Wallis test, $P=0.77$ ). Detailed statistical analysis for $1975-1995$ shows that nor has there been any trend in the return period of the annual maximum 24-, 48- and 72-h discharges, quantified using the respective mean flood frequency curves for the period: except in hurricane years the return periods are generally less than 10 years (Fallas and Valverde, 2007). This apparent lack of impact of forest cover change is probably due to two factors. First, the percentage change in forest cover is less than the approximately $20 \%$ change found from experience to be necessary for a measurable hydrological response (Bosch and Hewlett, 1982; Stednick, 1996; Bruijnzeel, 2004). Second, the coffee plantations mimic hydrologically important features of the natural forest, including a substantial litter layer that minimizes soil evaporation and impedes surface runoff. From the hydrological point of view, the apparent change in forest cover during 1970-2000 is therefore less than the $16.5 \%$ reduction represented by the loss of native forest. Analysis of the rainfall and runoff characteristics shows rather the dominating influence of rainfall on runoff: variations from the mean annual rainfall create corresponding variations from mean runoff (Fallas and Valverde, 2007). Thus, while the results do not provide a basis for testing the study hypothesis, they do help to define one of the criteria for a meaningful test, namely that the change in forest cover must exceed $20 \%$.

\subsection{Ecuador focus area}

The principal approach was to compare the flood responses of the paired catchments with contrasting vegetation covers for the 
same rainfall events, i.e. the Lise (largely forested) and Panamá (largely pasture) catchments and the Pinos (largely forested) and Pajonal (with extensive cattle grazing) catchments. The close proximity of the two catchments within each pair ensured that they were affected by the same rainfall events and regime. Nevertheless, their general location near the main Continental Divide is characterized by significant variations in rainfall volume even over small distances and the catchments can therefore have different annual rainfall totals (Table 2). From a mainly 2-year period of data collection (2006-2008, but with some additional data from 2009 and 2010) the corresponding daily peak discharges for a range of events were compared, to see if convergence occurred as the peak discharge increased. The results are shown in Fig. 4, where the discharges are normalized with area to allow for the different catchment sizes. In each case one of the catchments in each pair has a significantly lower annual runoff (Lise and Pinos), as a function of a lower forest cover and, possibly, smaller rainfall events (Table 2). At least in the lower discharge range these catchments also have lower peak discharges than the other half of their pair. In the case of the Lise/Panamá pair the difference in peak discharge remains approximately constant as the discharge magnitude increases. As a proportion of the discharge magnitude, though, the difference decreases, implying a relative convergence. In the case of the Pinos/Pajonal pair there is an apparent absolute convergence of peak discharge response at the highest discharges. Both cases are therefore consistent with the effect of forest cover on peak discharge becoming less important as the rainfall event magnitude increases. It is acknowledged that the patterns in Fig. 4 are dependent on just one extreme event data point in each case and therefore require confirmation with further data. Nevertheless, it is considered significant that the two patterns reinforce each other and neither shows a divergence with increasing discharge, which would contradict the test hypothesis.
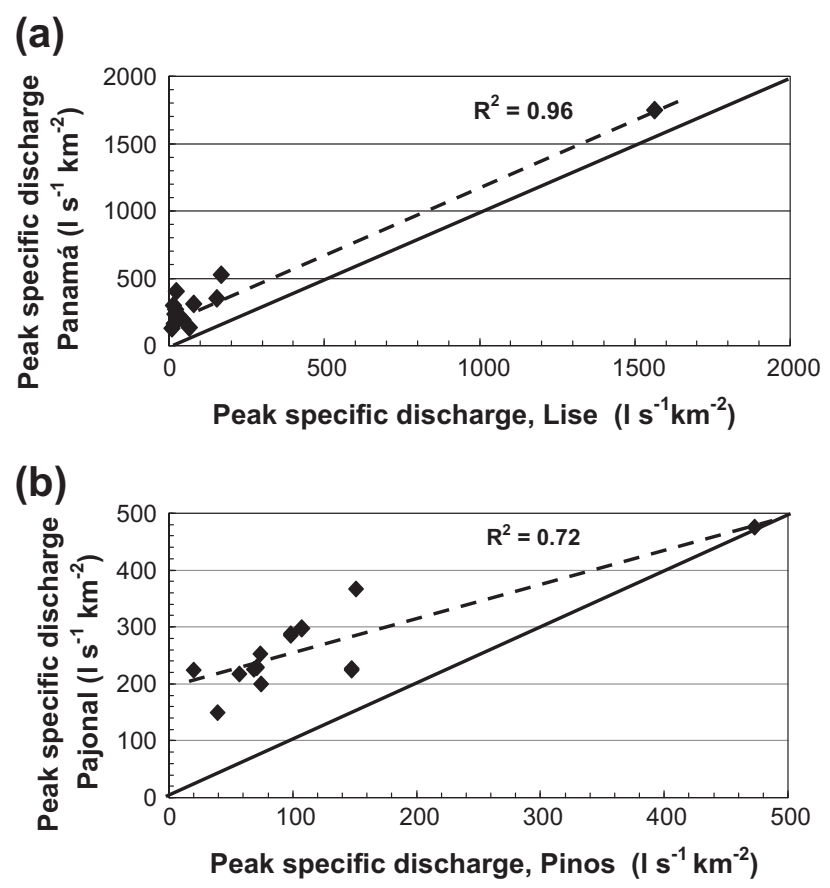

Fig. 4. Comparison of observed peak specific discharges for given rainfall events for: (a) the Panamá and Lise catchments; and (b) the Pajonal and Pinos catchments, Ecuador. Solid line is line of equality. Dashed fitted lines for the data show (a) relative and (b) absolute convergence of the catchment responses as discharge increases.
Given the short period of record it is not possible to calculate a reliable return period for the largest events and thus to define the conditions for convergence.

\subsection{Chile focus area}

The principal approach was to compare the responses of La Reina catchment for the approximately 3-year periods before (1997-1999) and after (2000-2002) logging. The latter period is short enough that the effects of the new plantation growth are negligible. Initial hydrological analysis by Iroumé et al. (2006a) shows the following:

- There was a net increase in mean annual runoff of $110 \%$ from the first period to the second; summer runoff in particular was increased. Such an increase appears consistent with the elimination of the interception capacity and the reduction in transpiration potential compared with the pre-logging conditions (e.g. Huber and López, 1993; Huber and Iroumé, 2001).

- The relationship between peak discharge and the size of the rainfall event (depth of rainfall) shows a small increase in peak discharge for a given rainfall event in the post-logging period, albeit with considerable scatter and overlap of data. Mean instantaneous peak discharges for the pre- and post-logging periods were 48.3 and $63.8 \mathrm{l} \mathrm{s}^{-1}$ respectively. This difference (statistically significant as determined by the $t$-statistic at a 95\% level) represents a mean increase in peak discharge of $32 \%$ following logging. On average, the volume of precipitation from the individual rainstorms that generated these peak flows was not significantly different ( $t$-statistic at a 95\% level) between the pre- and post-logging periods, thereby supporting the hypothesis that the increase in peak flows results from the loss of forest cover.

To test the hypothesis that forest cover has a lesser effect on peak discharges for larger events, the peak discharges for the pre- and post-logging periods were separated according to rainfall event size. An event was defined as a period of rainfall preceded and succeeded by at least five hours without rainfall. Small events were classed as $5-10 \mathrm{~mm}$, medium events as $10-50 \mathrm{~mm}$ and large events as greater than $50 \mathrm{~mm}$ (Primrose, 2004; Iroumé et al., 2006b). A summary of the data is shown in Table 3. Comparing the pre- and post-logging conditions (i.e. 1997-1999 versus 2000-2002), the percentage increases in median peak discharge are $189 \%, 74 \%$ and $62 \%$ for the small, medium and large events respectively. In other words the increase in peak discharge diminishes as the size of the rainfall event increases, in accordance with the hypothesis.

In addition the peak flow/rainfall depth relationships for the pre- and post-harvesting conditions were compared (Fig. 5). It is clear in each case that a given rainfall event can generate a wide range of peak discharges, presumably largely as a function of antecedent conditions. Given the scatter in the data, a variety of trend lines could be fitted to show the relationship between peak discharge and size of event (rainfall amount). However, as the axes are logarithmic in scale, power laws have been used in this case. The fitted line for the pre-logging period falls below the line for the post-logging period but the two clearly converge towards the largest events. Further, while both periods show a similar range of peak discharges for the largest rainfall events, the pre-logging period shows a rather wider range of peak discharges for small and moderate events than does the post-logging period. In other words, the range of responses converges strongly towards the larger events, again supporting the hypothesis.

The available data record at La Reina catchment is too short to provide a reliable estimate of the return period of the largest flood 
Table 3

Summary of median peak discharges for different rainfall event categories, for the pre-logging period and for each year of the post-logging period, La Reina catchment, Chile; numbers of events are shown in italics in brackets.

\begin{tabular}{llcc}
\hline Forest condition & Year & \multicolumn{2}{l}{ Median peak discharge $\left(\mathrm{l} \mathrm{s}^{-1}\right)$ for rainfall event category } \\
\cline { 2 - 4 } & & Small $(5-10 \mathrm{~mm})$ & Medium $(10-50 \mathrm{~mm})$ \\
\hline Pre-logging & $1997-1999$ & $4.6(40)$ & $18.5(94)$ \\
Post-logging & $2000-2002$ & $13.3(42)$ & $32.1(110)$ \\
\hline
\end{tabular}

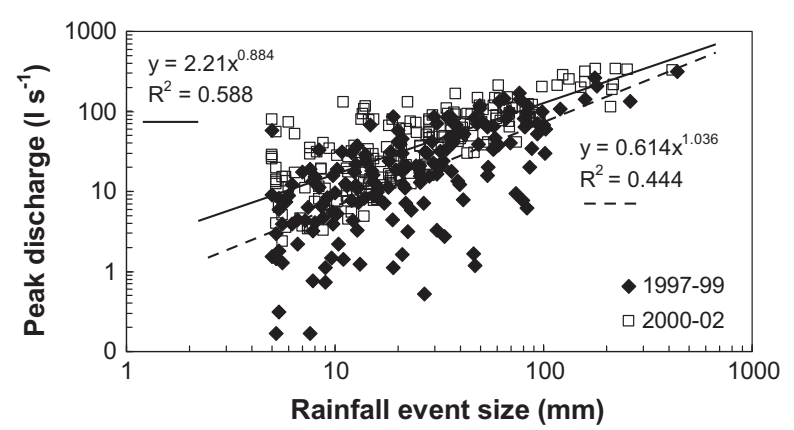

Fig. 5. Variation of peak discharge with event size (rainfall depth), comparing the pre-logging (1997-2000) and post-logging (2000-2002) periods at La Reina catchment, Chile; the data trends are indicated by fitted power laws.

events, which occurred in 2001 and 2002. The return periods were therefore determined for the largest events in these years for other sites in the region with longer term records of rainfall and discharge. By association with these sites, it was estimated that the return period for the largest peak discharges in La Reina catchment is in the range of 4-16 years (on average of the order of magnitude of 10 years) (Iroumé et al., 2008, 2010). This suggests that the peak discharges for the pre- and post-logging periods do not differ noticeably for discharge events with return periods greater than about 10 years. However, the regional catchments are rather larger than La Reina and this transfer of return periods should be treated with caution until it can be verified. On the whole, the results of the single catchment study support the test hypothesis. However, the scatter in the data, evident in the diagrams, indicates the complicating effects of controls such as antecedent soil moisture content, soil depth, vegetation type and season.

The analysis was extended to the three larger catchments in the Bíobío Region (Caramávida, Mulchén and Duqueco). From the late 1970 s to the early 1990 s, the percentage of the catchments covered by forest rose from $40 \%$ to $97 \%, 42 \%$ to $80 \%$ and $36 \%$ to $64 \%$ respectively. Analysis of the impact of the afforestation is complicated by an apparent increase in rainfall intensity from the pre- to post1979 period: for most rainfall stations in the region, return periods decrease for a given maximum 24 -h precipitation. To eliminate this effect, for each catchment, a series of pairs of equivalent rainstorms (and the associated peak discharges) was identified (one from the pre-plantation period, one from the post-plantation period). Each pair was constrained to a similar total event rainfall and accumulated precipitation for the previous 7 and/or 14 days. Plots of peak discharge against rainfall event size for the pre- and post-1979 periods and of the peak discharge before afforestation against the paired peak discharge after afforestation were then prepared. Figs. 6 and 7 illustrate the results for the Duqueco catchment but the patterns are remarkably consistent between all three catchments (Iroumé et al., 2008). Peak discharges are higher for the pre-afforestation conditions but the difference decreases as the size of the rainfall event and the peak discharge increase. Analysis of the discharge records suggests that the pre- and post-afforestation peak discharges differ noticeably only for discharge events with return periods lower than about 5 years, again supporting

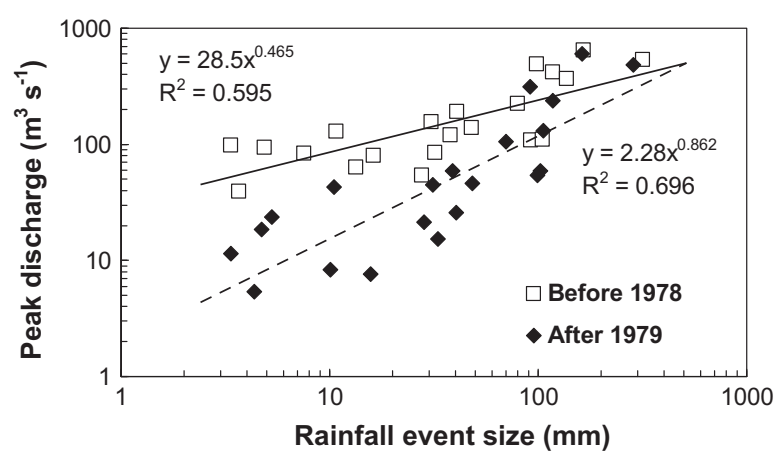

Fig. 6. Variation of peak discharge with event size (rainfall depth), comparing the pre-afforestation (before 1978) and post-afforestation (after 1979) periods at the Duqueco catchment, Chile; the data trends are indicated by fitted power laws.

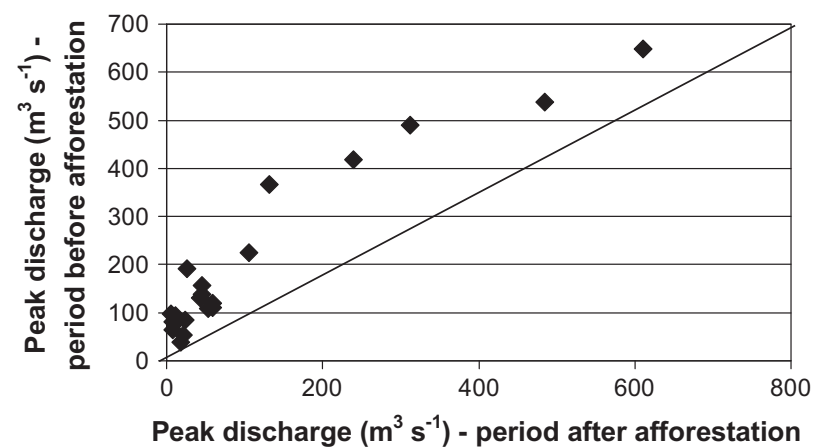

Fig. 7. Comparison of paired peak discharges from before and after forest plantation in Duqueco catchment $\left(1545 \mathrm{~km}^{2}\right)$, Chile; line is line of equality. The data show convergence of the catchment responses at high discharges. Reproduced from Bathurst et al. (2010) by permission of Taylor \& Francis Ltd (http:// www.informaworld.com).

the test hypothesis. The extension of this hypothesis to the larger catchment scales is in some contradiction to conventional thinking, which suggests that the impacts of change in forest cover become attenuated at the larger scales. In the Chilean case, the continued appearance of the effect may be due to the impressively industrial scale of the forestry activity, through which forest plantation and felling take place over very large areas almost simultaneously. In the three catchments, the percentage of the area affected by afforestation was in the approximate range of $30-60 \%$.

\subsection{Argentina focus area}

The data record for the largely unforested Hambre catchment was too short to allow comparison with the record for the partially forested Buena Esperanza catchment. Direct analysis of the impact of forest cover on peak discharges was therefore not possible. However, the data did allow an important cause of extreme floods to be identified. For both the Buena Esperanza and Hambre catchments, the largest floods are strongly linked to rain falling on snow in conditions of high temperatures and significant snow accumulation in 
the catchment (especially at the lower elevations where melting is more rapid). A greater frequency of rain-on-snow events and associated flood peaks was observed in the latter catchment, which has a greater proportion of lower elevations at which liquid precipitation is more likely, especially in the early winter. This suggests that, in these types of mountain catchment with both rain and snowmelt inputs, the frequency of large floods linked to rain-onsnow increases as the dominant elevation decreases. The extent to which the flood characteristics may be expected to vary with forest cover is then affected by the elevation within the catchment at which any forest occurs. Within the Buena Esperanza catchment tree cover (at the lower and middle elevations) acts as a barrier to the redistribution of snow by wind from higher elevations to the lower elevations, where higher temperatures would support more rapid thawing. This supports the view from the literature (presented in Section 2) that tree cover acts to reduce peak flows in rain-on-snow events. Further, the forest cover can affect the snow hydrology for only a limited part of the year. Snow accumulation is greatest at the lower elevations in August and September and by December the remaining snow is present in significant amounts only above the vegetation line.

\section{Discussion}

Only the Ecuador and Chile field experiments are able to address the central test hypothesis directly, i.e. that as the size of the hydrological event increases, the effect of forest cover becomes less important. However, the Costa Rica and Argentina experiments provide important contextual information for the test as well as a basis for the modelling analysis reported in the companion paper (Bathurst et al., 2011).

In general, the data from the focus areas show that, whatever the forest cover, larger rainfall and snowmelt events tend to cause larger peak discharges. The question, though, is the extent to which the responses to a given rainfall event differ between forest covers and between rainfall return periods. Here the Ecuador and Chile results for small catchments are in good agreement, showing differences in peak discharge response for smaller rainfall events but either relative or absolute convergence at larger events. Although there is uncertainty in the analysis, there is some suggestion that forest cover has negligible effect on the peak discharge for discharge return periods of more than about 10 years. This is consistent with the available literature on field experiments for small catchments, which suggests convergence of response for return periods greater than 5-10 years. The Chile focus site (La Reina) is in a geographical area with strong geomorphological and climatic similarities to the sites in the Pacific Northwest of North America analyzed by Jones and Grant (1996), Thomas and Megahan (1998) and Beschta et al. (2000). Consistency between these analyses might therefore be expected but its occurrence nevertheless adds strength to the results. The Ecuador sites, by contrast, extend the investigation into a very different environment of tropical mountains with a clear wet season and very distinctive soils. Consistency of the analysis for these sites with the Chile and earlier literature analyses helps to generalize support for the test hypothesis.

For larger catchments, the literature is less clear about the impact of forest cover on peak discharges, a position mirrored by the project results. For the Pejibaye (Costa Rica) catchment (area $131 \mathrm{~km}^{2}$ ), changes in forest cover over the study period apparently had little effect on the return periods of the annual maximum discharges. It is likely that the net reduction in cover, accounting also for the compensating increases in coffee plantation, did not reach the threshold which previous analyses show is needed to produce a response. The compensating effect of plantation appears to be similar to that found in the study of Pizarro et al. (2006) mentioned earlier. By contrast, the large Chile sites $\left(94,434\right.$ and $1545 \mathrm{~km}^{2}$ in area) show both an effect of forest cover on peak discharge response for smaller floods and a convergence of response at higher discharges. In other words they show that it is indeed possible for forest cover change to affect peak discharges at larger catchment scales while also supporting the test hypothesis. The large Chile catchments thus appear to act as scaled up versions of the small catchments. It is likely that this is because of the rather large percentage changes in forest cover in these catchments (approximately 30-60\%), coupled with rainfall events which were of sufficient spatial extent to affect most, if not all, of the full catchment area (noting, at least, that all the available raingauges recorded a rainfall.) These characteristics help to define the conditions needed for the results from small catchments to be extrapolated to larger areas. The flood return period of 5 years or greater needed for convergence of response in the large Chile catchments is a little lower but generally similar to the 10 years suggested for small catchments.

While the results for rain-fed catchments (especially small catchments) are beginning to create the basis for a general understanding of the impact of forest cover on flood peak discharge, the position for snowmelt remains unclear. The analysis carried out for the Argentina sites defines the conditions needed to produce extreme events and shows that forest cover interacts with snowmelt in a variety of ways but the data are not sufficient to disentangle the complex relationship between forest cover, event return period and peak discharge. The available literature suggests that loss of forest can increase snowmelt (or rain-on-snow) peak discharges but it is unclear if this effect extends to extreme events.

\section{Conclusions}

In the light of possible public misapprehensions concerning the role of forests in controlling floods, this paper set out to use field evidence from four Latin American countries to test the hypothesis that, as the size of the hydrological event increases, the effect of forest cover becomes less important. There have been relatively few previous studies and these have been dominated by the research in the Pacific Northwest of North America. This study extends the previous work into four different Latin American environments representing tropical and temperate rain forests and floods derived from hurricanes, El Niño events, mid-latitude depressions and snowmelt. Results for small paired catchments with different forest covers in Ecuador and for a small catchment subjected to forest logging in Chile suggest that the effect of forest cover on flood peak discharge does indeed diminish either relatively or absolutely as discharge increases and that convergence of response is likely for flood return periods of greater than about 10 years (although this figure requires further confirmation). These results agree with and extend those of previous studies. For larger catchments (up to $1500 \mathrm{~km}^{2}$ ), the results from Costa Rica and Chile suggest that there must be a change of at least $20-30 \%$ in forested area for a change in peak discharge to be measurable. However, it is then possible for the same effect of decreasing forest cover impact with increasing discharge to be observed. Convergence of response at the Chile sites was found for flood return periods of greater than 5 years. This finding adds a little clarity to the generally ambiguous results in the past literature. Considering, then, the popular perception that forests prevent floods, it may be noted that forests do not eliminate floods and are unlikely to reduce, significantly, peak flows generated by extreme rainfall. However, as proposed by López-Moreno et al. (2006), forest cover could be effective during more frequent, less intensive rainstorms, noticeably reducing the frequency and intensity of more moderate floods. 
The literature also indicates the important role of forest cover in reducing soil erosion and sediment yield.

The field studies carried out for the EPIC FORCE project represent a considerable effort by several teams of researchers, often in difficult physical conditions. They have extended the environments previously used in studying the effect of forest cover on peak discharge for extreme rainfall and snowmelt events and have significantly extended the analysis for small and large catchments. Nevertheless, most of the analyses are based on relatively short periods and do not contain many examples of extreme events. Their statistical basis is therefore limited. Also, while understanding has been advanced for rain-fed catchments, there is less clarity for snowmelt supplied sites. Further, conclusions about the true effect of forest cover on peak discharge for extreme events are complicated by the effects of seasonal conditions, soil moisture conditions, forestry activities such as road building and other catchment characteristics. As noted by Moore and Wondzell (2005), it is therefore difficult to generalize from the results and conclusive support for the test hypothesis is still lacking. However, it is possible to extract more information from the field data by using them to calibrate mathematical models which are then applied to scenario events, including extreme floods. Such applications allow a systematic and common analysis to be carried out across all the focus areas and can thus provide further insights into the controls on catchment response to forest cover change for extreme events. The companion paper (Bathurst et al., 2011) therefore describes a systematic modelling analysis of the four focus areas, representing very different environments and latitudes, which complements the field data analysis described above. Combining the field and modelling studies provides more powerful support for the test hypothesis than can the field study on its own.

\section{Acknowledgements}

The EPIC FORCE project was led by the University of Newcastle upon Tyne (UK). The other partners were the Università degli Studi di Padova (Italy), the Universidad Politécnica de Madrid (Spain), the Universidad Nacional de Costa Rica, the Universidad de Cuenca (Ecuador), the Universidad Austral de Chile, the Universidad Nacional de La Plata (Argentina) and the Secretaría de Desarrollo Sustentable y Ambiente de Tierra del Fuego (Argentina).The authors thank the following members of the Universidad de Cuenca team for their supporting work: Nur Algeet, Andres Alvarado, Patricio Crespo, Jan Feyen, Diego Mora, Paul Torres and Caroline Tote. The project was funded by the European Commission within the 6th Framework Programme as part of its programme of Specific Measures in Support of International Cooperation under Contract Number INCO-CT2004-510739, and this support is gratefully acknowledged. Two anonymous reviewers are thanked for their comments, which have helped to improve the paper.

\section{References}

Acón y Asociados, 1991. Manual descriptivo de la leyenda del mapa de asociaciones de subgrupos de suelos de Costa Rica Escala 1:200,000. Ministerio de Agricultura y Ganadería, Secretaría Ejecutiva de Planificación Sectorial Agropecuaria. San José, Costa Rica.

Amaranthus, M.P., Rice, R.M., Barr, N.R., Ziemer, R.R., 1985. Logging and forest roads related to increased debris slides in southwestern Oregon. J. Forest. 83, 229233.

Andréassian, V., 2004. Waters and forests: from historical controversy to scientific debate. J. Hydrol. 291, 1-27.

Bathurst, J.C., Amezaga, J., Cisneros, F., Gaviño Novillo, M., Iroumé, A., Lenzi, M.A., Mintegui Aguirre, J., Miranda, M., Urciuolo, A., 2010. Forests and floods in Latin America: science, management, policy and the EPIC FORCE project. Water Intl. 35 (2), 114-131.

Bathurst, J.C., Birkinshaw, S.J., Cisneros, F., Fallas, J., Iroumé, A., Iturraspe, R., Gaviño Novillo, M., Urciuolo, A., Alvarado, A., Coello, C., Huber, A., Miranda, M., Ramirez, M., Sarandón, R., 2011. Forest impact on floods due to extreme rainfall and snowmelt in four Latin American environments 2: model analysis. J. Hydrol. doi:10.1016/j.jhydrol.2010.09.001.

Beschta, R.L., Pyles, M.R., Skaugset, A.E., Surfleet, C.G., 2000. Peakflow responses to forest practices in the western cascades of Oregon, USA. J. Hydrol. 233 $102-120$.

Bosch, J.M., Hewlett, J.D., 1982. A review of catchment experiments to determine the effect of vegetation changes on water yield and evapotranspiration. J. Hydrol. 55, 3-23.

Bradshaw, C.J.A., Sodhi, N.S., Peh, K.S.-H., Brook, B.W., 2007. Global evidence that deforestation amplifies flood risk and severity in the developing world. Global Change Biol. 13, 2379-2395.

Bruijnzeel, L.A., 2004. Hydrological functions of tropical trees: not seeing the soil for the trees? Agr. Ecosyst. Environ. 104, 185-228.

Buytaert, W., Wyseure, G., De Bièvre, B., Deckers, J., 2005. The effect of land-use changes on the hydrological behaviour of Histic Andosols in south Ecuador Hydrol. Process. 19, 3985-3997.

Buytaert, W., Iñiguez, V., De Bièvre, B., 2007. The effects of afforestation and cultivation on water yield in the Andean páramo. Forest Ecol. Manage. 251, 22 30.

Calder, I.R., 1990. Evaporation in the Uplands. Wiley, Chichester, UK. 148pp.

Calder, I.R., 2005. Blue Revolution, Integrated Land and Water Resource Management, second ed. Earthscan, London. 353pp..

Calder, I.R., Aylward, B., 2006. Forest and floods: moving to an evidence based approach to watershed and integrated flood management. Water Intl. 31, 8799.

CIFOR, FAO, 2005. Forest and Floods: Drowning in Fiction or Thriving on Facts? <http://www.cgiar.org/insightdev/upload/291/145_BCIFOR0501.pdf>.

Cornish, P.M., 1993. The effects of logging and forest regeneration on water yields in a moist eucalyptus forest in New South Wales, Australia. J. Hydrol. 150, 301322.

Costa, M.H., Botta, A., Cardille, J.A., 2003. Effects of large-scale changes in land cover on the discharge of the Tocantins River, Southeastern Amazonia. J. Hydrol. 283 206-217.

Croke, J., Hairsine, P., Fogarty, P., 1999. Sediment transport, redistribution and storage on logged forest hillslopes in south-eastern Australia. Hydrol. Process. 13, 2705-2720.

Davies, P.E., Nelson, M., 1993. The effect of steep slope logging on fine sediment infiltration into the beds of ephemeral and perennial streams of the Dazzler Range, Tasmania, Australia. J. Hydrol. 150, 481-504.

DeGraff, J.V., Bryce, R., Jibson, R.W., Mora, S., Rogers, C.T., 1989. Landslides: their extent and significance in the Caribbean. In: Brabb, E.E., Harrod, B.L. (Eds.) Landslides: Extent and Economic Significance. Balkema, Rotterdam Netherlands, p. 68

DeWalle, D.R., 2003. Forest hydrology revisited. Hydrol. Process. 17, 1255-1256.

Duhalde Schwarzenberg, S.S., 1999. Estudio del proceso precipitatición-escorrentía en una microcuenca experimental de la Provincia de Osorno, Decima Región. Student thesis, Universidad Austral de Chile, Facultad de Ciencias Forestales, Valdivia (in Spanish).

Eschner, A.R., Patric, J.H., 1982. Debris avalanches in eastern upland forests. J. Forest $80,343-347$

Fahey, B., Jackson, R., 1997. Hydrological impacts of converting native forests and grasslands to pine plantations, South Island, New Zealand. Agr. Forest Meteorol. 84, 69-82.

Fallas, J., Valverde, C., 2007. Flood Response Analysis for Pejibaye Watershed, Costa Rica. <http://www.ceg.ncl.ac.uk/epicforce/assets/D15.pdf>.

FAO/ISRIC/ISSS, 1998. World Reference Base for Soil Resources. World Soil Resources Report 84, UN Food and Agriculture Organization, Rome.

Forsyth, T., 1998. Mountain myths revisited: integrating natural and social environmental science. Mt. Res. Dev. 18 (2), 107-116.

Grayson, R.B., Haydon, S.R., Jayasuriya, M.D.A., Finlayson, B.L., 1993. Water quality in mountain ash forests - separating the impacts of roads from those of logging operations. J. Hydrol. 150, 459-480.

Guthrie, R.H., 2002. The effects of logging on frequency and distribution of landslides in three watersheds on Vancouver Island, British Columbia Geomorphology 43, 273-292.

Hall, R.L., Calder, I.R., 1993. Drop size modification by forest canopies measurements using a disdrometer. J. Geophys. Res. 90, 465-470.

Hamilton, L.S., 1987. What are the impacts of Himalayan deforestation on the Ganges-Brahmaputra lowlands and delta? Assumptions and facts. Mt. Res. Dev. 7 (3), 256-263.

Harden, C.P., 2006. Human impacts on headwater fluvial systems in the northern and central Andes. Geomorphology 79, 249-263.

Huber, A., Iroumé, A., 2001. Variability of annual rainfall partitioning for different sites and forest covers in Chile. J. Hydrol. 248, 78-92.

Huber, A., López, D., 1993. Cambios en el balance hídrico provocados por tala rasa de un rodal de Pinus radiata (D. Don), Valdivia, Chile. Bosque 14 (2), 11-18.

Iroumé, A., Mayen, O., Huber, A., 2006a. Runoff and peak flow responses to timber harvest and forest age in southern Chile. Hydrol. Process. 20, 37-50.

Iroumé, A., Castillo, C., Primrose, H., Huber, A., Bathurst, J., 2006b. Respuesta de los caudales máximos al manejo de bosques de plantaciones en cuencas experimentales en el sur de Chile. In: Climate Variability and Change Hydrological Impacts, Proc. 5th FRIEND World Conference, La Havana, Cuba, Intl. Ass. Hydrol. Sci. Publ. No. 308, Wallingford, Oxon, UK, pp. 662-666 (in Spanish).

Iroumé, A., Huber, A., Palacios, H., 2008. Report on Basin Response for Chile. <http:// www.ceg.ncl.ac.uk/epicforce/assets/D17.pdf>. 
Iroumé, A., Palacios, H., Bathurst, J., Huber, A., 2010. Runoff and peakflows after clearcutting and the establishment of a new plantation in an experimental catchment, southern Chile. Bosque 31 (2), 117-128 (in Spanish).

Jones, J.A., Grant, G.E., 1996. Peak flow responses to clear-cutting and roads in small and large basins, western Cascades, Oregon. Water Resour. Res. 32 (4), 959-974.

Jost, G., Weiler, M., Gluns, D.R., Alila, Y., 2007. The influence of forest and topography on snow accumulation and melt at the watershed-scale. J. Hydrol. 347, 101-115.

La Marche, J.L., Lettenmaier, D.P., 2001. Effects of forest roads on flood flows in the Deschutes River, Washington. Earth Surf. Process. Landf. 26, 115-134.

Lane, P.N.J., Best, A.E., Hickel, K., Zhang, L., 2005. The response of flow duration curves to afforestation. J. Hydrol. 310, 253-265.

López-Moreno, J.I., Beguería, S., García-Ruiz, J.M., 2006. Trends in high flows in the central Spanish Pyrenees: response to climatic factors or to land-use change? Hydrol. Sci. J. 51 (6), 1039-1050.

Lyons, J.K., Beschta, R.L., 1983. Forest cover, floods, and channel changes: upper Middle Fork Willamette River, Oregon (1936-1980). Water Resour. Res. 19 (2), 463-471.

Mao, L., Comiti, F., Andreoli, A, Picco, L., Lenzi, M.A, Urciuolo, A., Iturraspe, R Iroumé, A., 2008. Role and management of in-channel wood in relation to flood events in Southern Andes basins. In: de Wrachien, D., Brebbia, C.A., Lenzi, M.A. (Eds.), Monitoring, Simulation, Prevention and Remediation of Dense and Debris Flow II. WIT Transactions on Engineering Sciences, vol. 60. WIT Press, Berlin, pp. 207-216.

Marks, D., Kimball, J., Tingey, D., Link, T., 1998. The sensitivity of snowmelt processes to climate conditions and forest cover during rain-on-snow: a case study of the 1996 Pacific Northwest flood. Hydrol. Process. 12, 1569-1587.

Mintegui, Aguirre J.A., Robredo, Sánchez J.C., 2008. Estrategias para el control de los fenómenos torrenciales y la ordenación sustentable de las aguas, suelos bosques de las cuencas de montaña. Technical Document 13, International Hydrological Programme for Latin America and the Caribbean, UNESCO Regional Science Office for Latin America and the Caribbean, Montevideo, Uruguay (in Spanish).

Monteith, S.S., Buttle, J.M., Hazlett, P.W., Beall, F.D., Semkin, R.G., Jeffries, D.S., 2006 Paired-basin comparison of hydrological response in harvested and undisturbed hardwood forests during snowmelt in central Ontario: I. Streamflow, groundwater and flowpath behaviour. Hydrol. Process. 20, 10951116.

Moore, R.D., Wondzell, S.M., 2005. Physical hydrology and the effects of forest harvesting in the Pacific Northwest: a review. J. Am. Water Resour. Assoc. 41 (4), 763-784.

Peel, M.C., Finlayson, B.L., McMahon, T.A., 2007. Updated world map of the KöppenGeiger climate classification. Hydrol. Earth Syst. Sci. 11, 1633-1644.
Phillips, C., Marden, M., Pearce, A., 1990. Effectiveness of reforestation in prevention and control of landsliding during large cyclonic storms. In: Proc. 19th IUFRO World Congress, Montreal.

Pizarro, R., Araya, S., Jordán, C., Farías, C., Flores, J.P., Bro, P.B., 2006. The effects of changes in vegetative cover on river flows in the Purapel river basin of central Chile. J. Hydrol. 327, 249-257.

Primrose, H., 2004. Peak Flow and Suspended Sediment Responses to Plantation Harvesting in the La Reina Catchment, Southern Chile. MSc Thesis, Newcastle University.

Reid, L.M., Dunne, T., 1984. Sediment production from forest road surfaces. Water Resour. Res. 20 (11), 1753-1761.

Robinson, M., Cognard-Plancq, A.-L., Cosandey, C., David, J., Durand, P., Führer, H.W., Hall, R., Hendriques, M.O., Marc, V., McCarthy, R., McDonnell, M., Martin, C., Nisbet, T., O'Dea, P., Rodgers, M., Zollner, A., 2003. Studies of the impact of forests on peak flows and baseflows: a European perspective. Forest Ecol. Manage. 186, 85-97.

Rowe, L.K., Pearce, A.J., 1994. Hydrology and related changes after harvesting native forest catchment and establishing Pinus radiata plantations. Part 2 . The native forest water balance and changes in streamflow after harvesting. Hydrol. Process. 8, 281-297.

Sáez García, J.O., 1999. Caracterización de la microcuenca experimental 'La Reina', provincia de Osorno, y su aplicación al Sistema Hidrológico Europea (SHETRAN). Student Thesis, Universidad Austral de Chile, Facultad de Ciencias Forestales, Valdivia (in Spanish).

Sikka, A.K., Samra, J.S., Sharda, V.N., Samraj, P., Lakshmanan, V., 2003. Low flow and high flow responses to converting natural grassland into bluegum (Eucalyptus globulus) in Nilgiris watersheds of South India. J. Hydrol. 270, 12-26.

Stednick, J.D., 1996. Monitoring the effects of timber harvest on annual water yield. J. Hydrol. 176, 79-95.

Storck, P., Bowling, L., Wetherbee, P., Lettenmaier, D., 1998. Application of a GISbased distributed hydrology model for prediction of forest harvest effects on peak stream flow in the Pacific Northwest. Hydrol. Process. 12, 889-904.

Thomas, R.B., Megahan, W.F., 1998. Peak flow responses to clear-cutting and roads in small and large basins, western Cascades, Oregon: a second opinion. Water Resour. Res. 34 (12), 3393-3403.

Van Dijk, A.I.J.M., van Noordwijk, M., Calder, I.R., Bruijnzeel, S.L.A., Schellekens, J., Chappell, N.A., 2009. Forest-flood relation still tenuous - comment on 'Global evidence that deforestation amplifies flood risk and severity in the developing world' by C.J.A. Bradshaw, N.S. Sodhi, K.S.-H. Peh and B.W. Brook. Global Change Biol. 15, 110-115.

Wilk, J., Andersson, L., Plermkamon, V., 2001. Hydrological impacts of forest conversion to agriculture in a large river basin in northeast Thailand. Hydrol. Process. 15, 2729-2748. 